Agro-Science Journal of Tropical Agriculture, Food, Environment and Extension Volume 19 Number 1 (January 2020) pp. $31-36$

ISSN 1119-7455

\title{
DETERMINANTS OF CONSUMPTION PREFERENCE OF LOCAL VERSUS IMPORTED RICE BRANDS IN ENUGU STATE, NIGERIA
}

\author{
*Nwachukwu C.U. and Achike A.I. \\ Department of Agricultural Economics, University of Nigeria, Nsukka, Nigeria \\ *Corresponding author’s email: uzo.cynthia@gmail.com
}

\begin{abstract}
This study examined the determinants of consumption preference of local versus imported rice brands in Enugu State, Nigeria. In Nigeria, rice is a cereal crop widely accepted and consumed as a staple crop both in urban and rural areas. Both imported and local brands are widely accepted, but there appears to be a hidden stereotype guiding consumer preference of each of the brands which this study wants to unveil. The research is set to examine consumption preference of the different brands of rice consumed and examine the preferred attribute of rice quality. Results are based on a questionnaire survey conducted among 106 consumers across twelve communities in six local government areas and three agricultural zones in Enugu State, Nigeria. Descriptive statistics and semantic differential scaling were used to analyse the data. Rice quality (75.7\%) and packaging (71.4\%) were the reasons consumers gave for their preference of the local rice brand and imported rice brand, respectively. The attribute that makes consumers prefer local rice brand include availability $(\overline{\mathbf{x}}=1.8)$, taste $(\overline{\mathrm{x}}=1.0)$, swelling capacity $(\overline{\mathrm{x}}=1.5)$, and minimal use of ingredients $(\overline{\mathrm{x}}=2.3)$. Consumers of imported rice brand prefer the brand because of its cleanliness $(\overline{\mathrm{x}}=2.3)$, full grain size $(\overline{\mathrm{x}}=2.5)$, and ease of preparation $(\overline{\mathbf{x}}=1.8)$. This study therefore was necessary to unravel the determinants of this preference for strategic policy decisions that may guide improvements in the production, processing and marketing of local rice brands for obvious positive contributions to the national income and gross domestic product.
\end{abstract}

Key words: consumer preference, local rice brands and imported rice brand

\section{INTRODUCTION}

Rice is one of the common foods consumed by every Nigerian. There is no occasion or gathering of people in which rice is not served. Therefore, rice is one of the major food crops cultivated by farmers in all agro-ecological zones of Nigeria (Daramola, 2005; Onwualu, 2012). In Africa, the popularity of rice in the people's diet is because it is quick to cook and tasty (Mohapatra, 2011). Rice is no longer considered a luxury, it has fast turned into a major staple food in the country as it is easier to prepare compared to other traditional cereals. Furthermore, urbanization and increase rate of women working outside the home has shifted consumer preferences from other staple food to rice and this led to the structural increase in consumption of rice in Nigeria (Adejumo-Ayibiowu, 2010).

The huge demand for rice by the populace is met both by locally produced and imported rice brands. Among the major rice-importing countries in Africa, Nigeria is rated first and second in the world (Tiamiyu et al., 2010). In 2013, Nigeria imported 3 million metric tons of rice (Statista, 2015). Rice production in 2013 was 3.1 million metric tonnes and the total consumption of milled rice in that same year was 5.3 million metric tonnes (International Rice Research Institute, IRRI, 2015).
This shows that Nigeria's local rice production is yet to meet the high demand of rice by its populace.

The rate at which rice is imported to meet consumer demand is the greatest issue Nigeria faces in being self-sufficient in rice production (Tiamiyu et al., 2010). This is because the incentives used in rice importation could have been invested in rice production. According to Rutsaert et al. (2013), several attributes have been identified that influence consumer purchase preference, they are the extrinsic attributes (packaging, brand, appearance and price) and the Intrinsic attribute (taste, texture or colour). Compared to imported rice, locally processed rice contains impurities (stones, chaff and other foreign materials), and this makes the process of preparing it longer. Recently, efforts are being made in Nigeria to improve locally produced rice through the Value Chain Development Programmes (VCDP).

The imported rice brand, with which the locally produced rice brand competes, is of high quality standard in terms of its cleanliness, packaging, price which is not met by most small hullers. This is as a result of the processing technology. In Nigeria, rice processing always includes both parboiling and milling (International Fertilizer Development Centre, IFDC, 2008). 
According to Rutsaert et al. (2013) and United States Agency International Development (USAID) (2009), the replacement of local rice brand with imported rice brand by urban consumers can be described by their perception that local rice brand contains impurities. Also, different varieties of local rice brand are contained in the same bag because the different varieties are purchased from various farmers and mixed up during milling.

Locally processed rice is normally semi-milled brown rice, de-hulled, not polished, with great colour variation (Cadoni and Angelucci, 2013; Johnson et al., 2013). There are some differences between locally processed rice and imported rice brands, they are: appearance, swelling capacity, taste and the homogeneity. These differences are the main determinants of price between locally produced rice and imported rice brand (Cadoni and Angelucci, 2013; Johnson et al., 2013).

Studies like Tiamiyu et al. (2010) and Futakuchi et al. (2013) indicate preference for imported rice brand to local rice brand, despite the acknowledged higher organoleptic properties of local rice. There have been reports on consumer criteria for selecting alternative types of rice in Togo and Africa, indicating much preference for imported rice brand relative to local rice brand because of the grain quality (Fiamohe et al. (2013; Rutsaert et al. (2013). Furthermore, Oyinbo et al. (2013) studied consumer preference of imported and locally produced rice in Kaduna State. This study analysed the determinants of consumption preference of local versus imported rice brands in Enugu State, Nigeria. This study will provide empirical information on the consumer preference of the different brands of rice consumed and the outcome can facilitate the formulation of policies on improving rice quality by processors.

\section{Objectives of the Study}

The broad objective of the study is to determine consumption preference of local versus imported rice brands in Enugu State, Nigeria. The specific objectives are to examine the consumer preference of the different rice brand consumed and identify the most preferred attribute of rice quality.

\section{MATERIALS AND METHODS \\ Study Area}

The study was conducted in Enugu State, which is one of the five states in the South-East, Nigeria. In terms of its economy the state is rural and agrarian, with most of its working population engaged in farming (National Bureau of Statistics, NBS, 2014). Enugu State lies between latitudes $5^{\circ} 56^{\prime} \mathrm{N}$ and $7^{\circ} 05^{\prime} \mathrm{N}$ of the equator and longitudes $6^{\circ} 53^{\prime} \mathrm{E}$ and $7^{\circ} 55^{\prime} \mathrm{E}$ of the Greenwich meridian (Enugu State Agricultural Development Project, ENADEP, 2009). The State has a population of 3,267,837 (National Population Commission, NPC, 2006).
According to ENADEP (2012), Enugu State comprises 17 local government areas (LGAs) which are divided into six agricultural zones namely Awgu (Awgu, Aninri and Oji River LGAs); Agbani (Nkanu East, Nkanu West and Enugu South LGAs); Udi (Ezeagu and Udi LGAs); Nsukka (Uzo-Uwani Igbo Etiti and Nsukka LGAs); Enugu Ezike (Udenu, Igbo-Eze North and Igbo-Eze South LGAs); and Enugu (Enugu North, Enugu East and Isi-Uzo LGAs).

\section{Sampling Technique and Sample Size}

Multistage sampling technique was used, in order to make data collection manageable and cost effective. In the first stage, three agricultural zones were purposively selected from six agricultural zones, and they included Enugu, Awgu and Nsukka agricultural zones. They were selected to ensure that major towns and urban areas in the state are captured.

In the second stage two local government areas were purposively selected from each agricultural zone to have a total of six local government areas for the study. They are Enugu North and Enugu East from Enugu agricultural zone, Awgu and Aninri from Awgu agricultural zone and Nsukka and Uzo-uwani from Nsukka agricultural zone. The purposive selection was to at least capture two LGAs that are into rice production.

In the third stage two communities were purposively selected from each local government area amounting to twelve communities. Finally ten respondents were chosen from each community (Ogui-Nike, Emene, Abakpa, Ugbodogwu, Nsukka and Opi who do not produce rice but are consumers while Opanda, Mgbowo, Awgu, Oduma, Nenwe and Adani produce and also consume rice). Respondents especially the producers were selected from the list of rice producers in the communities. The total respondent sampled was 120 but 106 questionnaires were returned.

\section{Data Collection and Analysis}

Primary data were collected with the use of quantitative method for this study. The quantitative data was collected with the use of well-structured questionnaire designed in a way to elicit responses that fully captured the objectives. The questionnaire asked questions on the socio-economic characteristics of the respondents, the brand of rice consumed whether imported or local rice brand, reasons for preference of one rice brand over another and the factors that influence the preference of the different brands of rice consumed. The last question was realized with semantic differential scale, measured with a 7-point scale ranging from $3,2,1,0,-3,-2,-1$. The negative scale indicates the negative aspect of the rice brand preferred while the positive scale indicates the positive aspect. The data were analysed with descriptive statistics such as frequency distribution, percentages, mean including semantic differential scale with the use of Excel and SPSS. 


\section{RESULTS AND DISCUSSION}

Socio-economic characteristics of respondents

The socio-economic characteristics of the respondents are presented in Table 1 below. The age distribution of respondents in Table 1 shows that $16.0 \%$ of the respondents are within the age range of $46-55$ years, $19.8 \%$ are within the age range of $16-25$ years, $27.4 \%$ are within the age of $36-45$ years, and $28.3 \%$ of the respondents are within the age of 26-35years, the mean age of all the respondents is 37.0 years. None of the respondent was above 65 years of age. This indicates that they are young and within the middle age range, capable of making their own decisions on the rice brands they consume. This corroborates with the findings of Ogundele (2014) who reported that those in active working age may prefer calorie supplied food such as carbohydrates.

The results of the gender distribution in Table 1 showed that majority $(95.3 \%)$ of the respondents are females while the remaining $(4.7 \%)$ are males. This indicates that females are relatively more involved in general food consumption in the family as home makers. This is in line with the findings of Danso-Abbeam et al. (2014) that when it comes to household decision making as regards household food consumption women are mostly in charge. It also corroborates the findings of Onya et al. (2019) that women are in charge of the household kitchen as seen in African tradition.

Marital status plays an important role in feeding pattern as single people tend to eat out and eat whatever is available and presented. Rice consumers in this area were mostly married $(71.7 \%)$, while $24.5 \%$ were single and the rest widowed $(3.8 \%)$. This agrees with Ogundele (2014) that as a form of socializing with family members, a married person forms the habit of eating at home and this in turn will affect the type and quality of food consumed by the household. It also agrees with Onya et al. (2019) that marital status determines the preference and expenditure decisions of the households especially when it comes to consumption decisions.

Table 1: Distribution of rice consumers by socioeconomic characteristics

\begin{tabular}{llccc}
\hline \multicolumn{2}{l}{$\begin{array}{l}\text { Socioeconomic } \\
\text { characteristics }\end{array}$} & Frequency & Percentage & Mean \\
\hline Age & $16-25$ & 21 & 19.8 & \\
(years) & $26-35$ & 30 & 28.3 & \\
& $36-45$ & 29 & 27.4 & \\
& $46-55$ & 17 & 16.0 & \\
& $56-65$ & 9 & 8.5 & 37.0 \\
& Total & 106 & 100.0 & \\
Sex & Female & 101 & 95.3 & \\
& Male & 5 & 4.7 & \\
Marital & Total & 106 & 100.0 & \\
status & Married & 76 & 71.7 & \\
& Single & 26 & 24.5 & \\
& Widowed & 4 & 3.8 & \\
House- & Total & 106 & 100.0 & \\
hold & 6-10 & 61 & 57.5 & \\
size & $11-15$ & 36 & 34.0 & \\
& Total & 2 & 8.5 & \\
\hline Source: Field Survey, 2015 & 106 & 100.0 & 4.7 \\
\hline
\end{tabular}

It could be seen from Table 1 below that majority of the household size of the consumers fall within the range of $1-5(57.5 \%), 6-10(34.0 \%)$ and 11 and above $(8.5 \%)$ and the mean rank is 4.7 . This implies that the size of the household will determine to an extent the quantity and quality of food intake and the rice brand to consume. Bamidele et al. (2010) stated large households with less per capita income will consume more of the cheaper local rice as opposed to those with small households.

\section{The Consumer Preference of the Different Brands of Rice Consumed}

From the data in Table 2, it was found that local rice brand consumers $(75.7 \%)$ preferred the rice quality while imported rice brand consumers (24.3\%) preferred the rice brand because of the quality. This means that local rice consumption is popular among rice consumers in Enugu State. This agrees with Obih and Baiyegunhi (2018) who found out that there is general acceptability of local rice brands among rice consuming households in Nigeria. The rice qualities here according to consumers are perceived from different angles. The imported rice brand consumers perceive the quality in terms of absence of foreign materials (stones, chaff, debris). While the consumers of local rice brand perceive quality in terms of the nutrient content and also absence of foreign materials, some local rice brands are now processed to look exactly as the imported brand. This is inconsistent with the findings of Oyinbo et al. (2013) that rice quality (cleanliness, whiteness, shape and breakage of grain) was positively related to the households' consumption preference probability for foreign and local rice. This is also confirmed by Bamidele et al. (2010) that because the imported rice is of higher quality and grade, households prefer imported rice to local rice.

Then price is the second reason that the consumers of the different brands of rice prefer in the consumption of rice. Local rice brand consumers $(88.0 \%)$ indicated that price of the rice is the second reason that draws them into preference of the local rice brand over imported rice brand meanwhile; consumers that preferred imported rice brand indicated that they preferred the brand because of the price $(12.0 \%)$. According to Lançon et al., (2003) several consumers view high price as a measure of high quality therefore high prices would be synonymous with high quality rice and therefore used as a basis for selecting the product. They also stated that local rice is purchased by customers for its price and taste.

The package does not actually influence the purchase of the local rice brand. This means that consumers that consume local rice brand $(28.6 \%)$ are indifferent about the packaging of the rice. Most of the consumers $(71.4 \%)$ of imported rice brand prefer packaging of the rice brand. It is then assumed that 
Table 2: Distribution of consumer preference of the different brands of rice consumed

\begin{tabular}{|c|c|c|c|c|c|c|c|}
\hline \multirow[t]{2}{*}{ Reasons for preference/Brand of rice consumed } & \multicolumn{2}{|c|}{ Price } & \multicolumn{2}{|c|}{ Package } & \multicolumn{2}{|c|}{ Rice quality } & \multirow[t]{2}{*}{ Total } \\
\hline & Frequency & $\%$ & Frequency & $\%$ & Frequency & $\%$ & \\
\hline Imported & 3 & 12.0 & 5 & 71.4 & 18 & 24.3 & 26 \\
\hline Local & 22 & 88.0 & 2 & 28.6 & 56 & 75.7 & 80 \\
\hline Total & 25 & 100.0 & 7 & 100.0 & 72 & 100.0 & 106 \\
\hline
\end{tabular}

Source: Field Survey, 2015

packaging the local rice as a part of branding will not make any difference to them, but if the rice quality is improved alongside packaging, it will attract more consumers to patronize the local rice brand. This is not in consonance with DansoAbbeam et al. (2014) who stated that the most dominant constraints hindering consumers preference for local rice is poor packaging.

Preferred Rice Quality Attributes by Consumers From Table 3a, the preferred attributes for imported rice brand are cleanliness $(\overline{\mathrm{x}}=1.9)$, full grain size $(\overline{\mathrm{x}}=2.5)$, availability $(\overline{\mathrm{x}}=2.4)$ (search attribute), taste $(\overline{\mathrm{x}}=2.3)$, ease of preparation $(\overline{\mathrm{x}}=1.8)$, aroma and swelling capacity (2.8) (experience attribute). It was seen also that the aroma is preferred by both consumers of local and imported rice brand on the same mean value of 2.8. This corroborates Okeke et al. (2015) and Bamidele et al. (2010) who reported that household heads purchase imported rice because of its cleanliness, higher quality and grade, it has a better taste, polished, has full grain size and is free of stones and other impurities.
From Table 3b, it was seen that preferred attributes of rice quality for local rice brand are availability $(\overline{\mathrm{x}}=1.8)$ (search attribute) taste $(\overline{\mathrm{x}}=$ $1.0)$, swelling capacity $(\overline{\mathrm{x}}=1.5)$, aroma $(\overline{\mathrm{x}}=2.8)$ and minimal use of ingredients $(\overline{\mathrm{x}}=2.3$, $)$ (experience attribute). These are positive attributes that attract the respondents to local rice brand. From the analysis, it is seen that the local rice brand have some good attributes that when included in improving other qualities such as cleanliness, good package and full grain size, will compete with imported rice quality and also increase demand. This is also in consonance with Danso-Abbeam et al. (2014) who reported that the most dominant constraints hindering consumers preference for local rice is poor packaging with the mean rank of 2.32. Ogundele (2014) stated that the consumers of Pategi and Igbemo (local rice) found a better taste in its consumption. Figure 1 is a semantic differential scale chart showing the different attributes that consumers' prefer in the choice of rice brand they consume.

Table 3a: Preferred attribute of rice quality for imported rice brand

\begin{tabular}{|c|c|c|c|c|c|c|c|c|c|}
\hline Imported rice brand & 1 & 2 & 3 & 4 & 5 & 6 & 7 & Total & Mean \\
\hline Good package (GP) & 8 & 2 & 6 & 2 & 5 & 0 & 3 & 26 & 3.2 \\
\hline Cleanliness (CL) & 14 & 6 & 4 & 0 & 1 & 0 & 1 & 26 & 1.9 \\
\hline Full grain size (FGS) & 12 & 4 & 4 & 0 & 4 & 1 & 1 & 26 & 2.5 \\
\hline Availability (A) & 13 & 2 & 5 & 0 & 5 & 1 & & 26 & 2.4 \\
\hline Tasty (TY) & 13 & 3 & 6 & & 2 & & 2 & 26 & 2.3 \\
\hline Swelling capacity (SC) & 7 & 8 & 6 & & 1 & 1 & 3 & 26 & 2.8 \\
\hline Easy to prepare (EP) & 12 & 9 & 3 & 1 & 1 & 0 & 0 & 26 & 1.8 \\
\hline Aroma (AR) & 11 & 4 & 3 & 0 & 5 & 1 & 2 & 26 & 2.8 \\
\hline Minimal use of ingredients (MINI) & 2 & 2 & 7 & 1 & 1 & 6 & 7 & 26 & 4.6 \\
\hline Stickiness (ST) & 4 & 3 & 5 & 0 & 2 & 1 & 11 & 26 & 4.5 \\
\hline Same colour (SV) & 6 & 4 & 4 & 0 & 4 & 3 & 5 & 26 & 3.8 \\
\hline
\end{tabular}

Source: Field Survey, 2015. No. of consumers that preferred imported rice $=26$

Table 3b: Preferred attribute of rice quality for local rice brand

\begin{tabular}{|c|c|c|c|c|c|c|c|c|c|}
\hline Local rice brand & 1 & 2 & 3 & 4 & 5 & 6 & 7 & Total & Mean \\
\hline Poorly packaged (PP) & 6 & 2 & 8 & 13 & 20 & 5 & 26 & 80 & 5.0 \\
\hline Full of chaff (FC) & 10 & 11 & 14 & 3 & 16 & 12 & 14 & 80 & 4.2 \\
\hline Broken grain size (BGS) & 26 & 9 & 13 & 2 & 15 & 6 & 9 & 80 & 3.3 \\
\hline Non-availability (NA) & 38 & 21 & 17 & 1 & 3 & 0 & & 80 & 1.8 \\
\hline Tasteless(TL) & 75 & 15 & 0 & & 0 & & 0 & 80 & 1.0 \\
\hline Non-swelling capacity (NSC) & 48 & 22 & 8 & & 1 & 1 & 0 & 80 & 1.5 \\
\hline Not easy to prepare (NEP) & 19 & 13 & 12 & 3 & 15 & 4 & 14 & 80 & 3.6 \\
\hline No aroma (NAR) & 31 & 11 & 15 & 3 & 11 & 6 & 3 & 80 & 2.8 \\
\hline Much use of ingredients (MUI) & 20 & 33 & 11 & 15 & 1 & 0 & 0 & 80 & 2.3 \\
\hline Not sticky (NS) & 12 & 16 & 16 & 6 & 5 & 9 & 10 & 80 & 3.3 \\
\hline Colour variation (CV) & 9 & 17 & 24 & 8 & 15 & 3 & 4 & 80 & 3.2 \\
\hline
\end{tabular}

Source: Field survey, 2015; No. of consumers that preferred locally processed rice $=80$ 


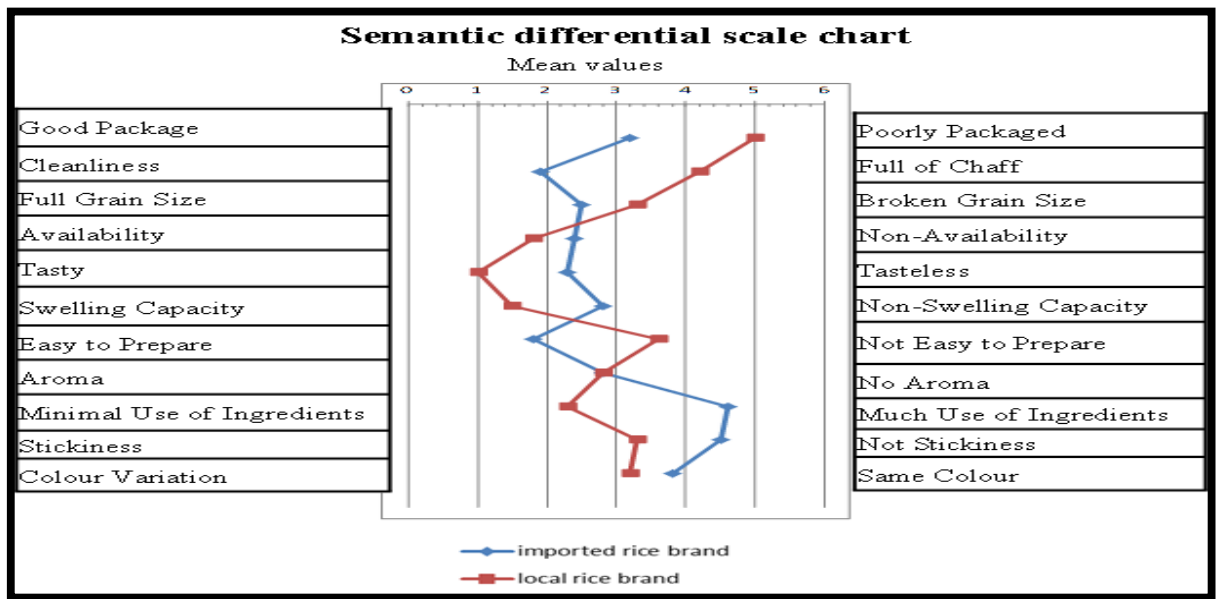

Figure 1: Semantic differential chart of rice quality for local and imported rice brand Source: Field survey, 2015

\section{CONCLUSION AND RECOMMENDATION}

Despite the fact that the imported rice brand has preferred attributes of cleanliness, full grain size, easy to prepare and good package. The local rice brand with its own attributes of swelling capacity, availability, minimum use of ingredients and taste is seen to be the choice of most consumers in this study. Therefore, this study was necessary to unravel the determinants of this preference for strategic policy decisions that may guide improvements in the production, processing and marketing of local rice brands for obvious positive contributions to the national income and gross domestic product.

\section{RECOMMENDATIONS}

It can be seen that local rice brand have some good attributes that when included in improving other qualities such as cleanliness, good package and full grain size will compete with imported rice quality and also increase demand. The ban on importation of foreign rice brand should be adhered to strictly encourage the production of local rice brand and hence increase consumption and the incentives saved in doing so should be invested in local rice production to increase the quantity and the quality of local rice brand.

\section{REFERENCES}

Adejumo-Ayibiowu D. (2010). Mapping of poverty reduction strategies papers (PRSP), sector strategies and policies related to rice development in Nigeria. Paper prepared for the Coalition of African Rice Development (CARD) November 2010. Retrieved from www.riceforafrica.org

Bamidele F.S., Abayomi O.O. and Esther O.A. (2010). Economic analysis of rice consumption patterns in Nigeria. Journal of Agric. Sci. Technol., 12, 1-11

Cadoni P. and Angelucci F. (2013). Analysis of incentives and disincentives for rice in Nigeria. Technical Notes Series, MAFAP, FAO, Rome. Retrieved from www.fao.org
Danso-Abbeam G., Armed M. and Baidoo F. (2014). Determinants of consumer preference for local rice in Tamale Metropolis, Ghana. International Journal of Education \& Social Science, 1 (2), 114-122. Retrieved from http://www.ijessnet.com

Daramola B. (2005). Government policies and competitiveness of Nigerian rice economy. Paper Presented at the Workshop on Rice Policy \& Food Security in Sub-Saharan Africa, organized by WARDA, Cotonou, Republic of Benin, Nov. 07-09, 2005. Retrieved from http://www.africaricecenter.org

Enugu State Agricultural Development Programme. (2009). Annual Report: 36

Enugu State Agricultural Development Programme. (2012). Director, Planning, Ministry of Agriculture, Enugu State

Fiamohe R., Seck, A., Nakelse T. and Diagne A. (2013). Assessing the effect of consumer purchasing criteria for types of rice in Togo: a choice modelling approach. Invited Paper Presented at the 4th International Conference of the African Association of Agricultural Economists, Sep. 22-25, 2013, Hammamet, Tunisia. Retrieved fromageconsearch.umn.edu

Futakuchi K., Manful J. and Sakurai T. (2013).Improving grain quality of locally produced rice in Africa. $C A B$ Int. 2013, Realizing Africa's Rice Promise, 311-323

International Fertilizer Development Centre (2008). Study of the domestic rice value chains in the Niger Basin of Mali, Niger, and Nigeria, West Africa. An International Centre for Soil Fertility and Agricultural Development. African Division. Retrieved from http://www.commonfund.org

International Rice Research Institute (2015). World Rice Statistics Online Query Facility. Retrieved from ricestat.irri.org

Johnson M., Takeshima H. and Gyimah-Brempong K. (2013). Assessing the potential and policy alternatives for achieving rice competitiveness and growth in Nigeria. IFPRI discussion paper 01301 Nov. 2013. Retrieved from http://www.ifpri.org

Lançon F., Erenstein O., Akande S.O., Titilola S.O., Akpokodje G. and Ogundele O.O. (2003). Imported rice retailing and purchasing in Nigeria: a survey. West African Rice Development Association (WARDA), Abidjan, Côte d'Ivoire. Retrieved from http://www.inter-reseaux.org 
Mohapatra S. (2011). Quality matters. Rice Today JanMar 2011, 36

National Bureau of Statistics (2014). Enugu State Information. Retrieved from http://www.nigerianstat.gov.ng

National Population Commission (2006). Official Census Report, Abuja, Nigeria

Obih U. and Baiyegunhi L. (2018). Consumers' acceptability of local rice brands in Nigeria. Which marketing functions really matter? Journal of Agribusiness \& Rural Development, 2(48), 183-196. http://dx.doi.org/10.17306/J.JARD.2018.00412

Ogundele O. (2014). Factors influencing consumers' preference for local rice in Nigeria. African Journal of Marketing Management, 6 (4), 49-55. DOI: 10.5897/AJMM2011.048

Okeke A.M., Iheanacho A.C. and Obasi C.C. (2015). Determinants of local rice consumption among households in Markurdi Metropolis of Benue State. Int Journal of Food Science \& Technology, 5 (1), 1-10

Onwualu P. (2012). Agricultural sector and national development: Focus on value chain approach Presented at the 5th Edition of the Annual Lecture of Onitsha Chamber of Commerce. Retrieved from www.rmrdc.gov.ng

Onya S.C., Okezie C.A. and Ejiba I.V. (2019). Double hurdle modeling approach to local rice consumption in Ikwuano Local Government Area of Abia State, Nigeria. Agro-Science, 18 (2), 20-25. DOI: http://dx.doi.org/10.4314/as.v18i2.4
Oyinbo O. Omolehin R. and Abdulsalam Z. (2013). Household consumption preference for imported and domestic rice in Kaduna State, Nigeria: Implication for rice quality improvement. Journal of Production, Agriculture \& Technology, 9 (1), 29-37. Retrieved from patnsukjournal.net/Vol9N01/P4

Rutsaert P., Demont M. and Verbeke W. (2013). Consumer preference of rice in Africa. CAB Int., Realizing Africa's rice promise, 294-302. Retrieved from http://www.warda.cgiar.org

Statista (2015). Principle rice importing countries worldwide. Retrieved from www.statista.com

Tiamiyu S.A., Usman S.A., Gbanguba A. Ukwungu A.U. and Ochigbo A.A. (2010). Assessment of quality management techniques: toward improving competitiveness of Nigerian rice. In: Innovation and Partnership to Realize Africa's Rice Potential, Proc. of the Second Africa Rice Congress, Bamako, Mali, 22-26 March 2010. Africa Rice Centre, Cotonou, Benin. Retrieved from http://www.africarice.org

United States Agency International Development (2009). The global food security response West Africa rice value chain analysis. Retrieved from www.microlinks.org 